\title{
Poor Management of Low Birth Weight Compounds Obesity and Chronic Diseases in Cuba
}

\author{
Manuel Hernández-Triana MD PhD
}

\begin{abstract}
The Cuban population exhibits high prevalence of overweight and associated chronic non-communicable diseases, trends that begin in childhood. In addition to factors related to the mother's health, factors contributing to excess weight gain in Cuban children are: reduced prevalence of exclusive breastfeeding of infants up to six months of age, full-term low birth weight infants and nutritional mismanagement of this group, incorrect complementary feeding, obesogenic diet, family history and sedentary lifestyles. Thus, it is important to adopt comprehensive, multisectoral strategies that promote adequate nutrition and weight control. This is particularly important for full-term low birth weight infants, predisposed to body fat storage.
\end{abstract}

KEYWORDS Low birth weight, obesity, diabetes, inflammation, breastfeeding, diet, physical activity, lifestyle, children, adolescents, Cuba

\section{INTRODUCTION}

Excess body weight (overweight and obesity) is defined as excess body fat. Indicators - such as weight and height for age, and body mass index (BMI) for age-are used to diagnose excess body weight in adults and children. These indicators are estimated for each individual and compared with national or international growth standards, such as those of the WHO.[1] Among the factors strongly associated with increased risk of obesity later in life are: inadequate caloric, protein and micronutrient intakes during pregnancy, low birth weight (LBW), non-exclusive breastfeeding during the first six months of life, high protein consumption during early childhood, low quality complementary feeding (poor in micronutrients and essential fats) and rapid weight gain during the first two years of life.[2]

The relationship between excess weight gain over the life span and increased risk of major chronic non-communicable diseases (NCD) has been well established.

At the end of the 1980 s, $31.5 \%$ of Cuban men and $39.4 \%$ of Cuban women were overweight.[3] As a result of the economic crisis of the 1990s, the adult population registered an average 4-5 kg weight loss followed by a rebound in the first half decade of economic recovery. Excess body weight in the Cuban population increased from $33.5 \%$ in 1995 to $42.6 \%$ in 2001 and $43.8 \%$ in 2010.[3,4] This was accompanied by increased diabetes prevalence (116\%) and incidence (140\%) between 1997 and 2009,[3,4] according to data available from the Continuous Assessment and Risk Evaluation (CARE) registry for this period. The registry covered $61.2 \%$ of the population $(n=5,951,088)$ in $1979,75.9 \%$ $(n=7,918,647)$ in 1989 , and $98.2 \%(n=11,038,820)$ in 2009, the latter proportion facilitated by implementation of the family doctor-and-nurse program, placing these professionals in communities throughout Cuba.[5,6] Franco reported that diabetes mortality increased by $49 \%$ between 2002 and 2010 (from 9.3 to 13.9 deaths per 10,000 ), and noted a deceleration of the decline in coronary heart disease mortality rates.[4]
According to data from Cuba's Food and Nutrition Surveillance System and studies conducted by the National Growth and Development Group, excess body weight in children $<5$ years increased from 13.5\% to $17.4 \%$ between 2004 and 2011 (using national standards), and from $23 \%$ to $31 \%$ in children aged 6-24 months.[3] Such substantial increases were consistent with reports published in 2005 and 2008 on early atherogenic signs[7] and type 2 diabetes[8] among Cuban children and adolescents, as well as data from a 2006 report indicating that nonalcoholic fatty liver was found in $48 \%$ of obese Cuban children aged 4-16 years.[9]

Cuba's per capita expenditures for diabetes care alone (US\$1219) were the highest in Latin America in 2000[10] and likely have risen considerably in the ensuing 14 years with the growing international economic crisis, exacerbating the impact of diabetes on individual health and quality of life. Predicted increased rates of diabetes in Cuban adults[11] undoubtedly will add to this already heavy toll in both financial and human terms.

In 2012, the UK Health Forum and Oxford University published results of micro-simulation models to project to 2050 the BMI- and obesity-related NCD trends, by age and sex, for ten Latin American countries. The highest rates for diabetes and obesity in both men and women were predicted for Cuba.[11] Based on the WHO BMI database and UNFPA demographic statistics for 2011,[12] there will be $>1.34$ million people aged $\geq 20$ years with coronary heart disease or stroke in Cuba by $2030 ; 220,000$ with cancer, and 1.03 million with diabetes.

The publication also reported that effective interventions to reduce prevalence of excess body weight could have a major effect on cumulative incidence of chronic NCDs by the year 2030.[11] The highest impact would likely occur in Cuba, where it was predicted that $>2000$ cases of type 2 diabetes and $>1300$ cases of coronary heart disease and stroke per 100,000 population could be avoided by a mere $5 \%$ reduction in obesity $(\mathrm{BMI}>30)$ rates.[11]

In Cuban children, higher rates of excess body weight, coinciding with deficiency-related NCDs such as anemia,[13] impose a double burden on the health system, requiring design of more targeted health programs and interventions for pregnant women, infants, and children during the first two years of life. This in turn necessitates more precise identification of the main factors contributing to excessive weight gain and glucose intolerance in childhood, as described below.

Particular attention is paid to improvements needed in nutritional management of full-term LBW newborns, since while prevalence of LBW in Cuba is very low (about $5 \%$ over the last decade; in 2013, 6369 LBW infants),[14] poor nutritional habits in this group can and have led to over-feeding, increasing their body weight and adiposity, creating a health problem.[15] 


\section{STUDIES ON CAUSES OF OVERWEIGHT}

\section{AND OBESITY IN CUBAN CHILDREN}

Factors identified as contributing to increased overweight and obesity in Cuban children and adolescents include: poor nutritional status of women of childbearing age, iron deficiency anemia before and during pregnancy, smoking and illnesses during pregnancy, LBW, non-exclusive breastfeeding to age six months, and promotion of rapid catch-up growth in LBW infants with diets deficient in micronutrients and high in sugar and other refined hydrocarbons.[12-22]

The following research examples provide more detailed evidence regarding diet, physical activity and certain genetic and family lifestyle factors, as well as the association of excessive weight gain to health outcomes in Cuban children.

Diet Studies conducted between 2000 and 2013, comprising 873 children and adolescents $4-16$ years of age (56 preschoolers, 768 school-age children and 49 adolescents), showed high intake of refined carbohydrates and animal fat, fast foods and sugary drinks; also, low intake of fruits, vegetables, and micronutrients. Sugar intake was twice the Cuban recommended limit of $10 \%$ of total daily energy intake established by Cuba's Nutrition and Food Hygiene Institute (INHA). [23] The researchers used isotopic methods to measure body composition, physical activity and total daily energy expenditure; and surveys by INHA provided data on ingestion of food and nutrients (obtained through semiquantitative dietary surveys, 24-hour food diaries, or weighing food consumed over three days).[19] These results coincided with those regarding the general Cuban population.[24] In some of the groups under study, one in every three children consumed three times the maximum recommended amount of sugar, which promotes body fat accumulation and development of NCDs in adulthood. Additional health risks were also identified from high sodium content in food consumed, even before any table salt was added.[19]

Physical activity In the year 2000, INHA started a project (still ongoing) in collaboration with the UN International Atomic Energy Agency to identify factors contributing to excess body weight in the Cuban population. Studies of preschoolers living in different geographic areas of Cuba showed the effect of urbanization on reducing physical activity.[25] Boys from urban areas were more sedentary than their counterparts in small towns or rural areas. All preschool girls exhibited sedentary behavior, irrespective of place of residence, revealing the role that gender plays from childhood in the higher prevalence of excess body weight in Cuban women. [3] The children under study had daily energy expenditures similar to those of children in highly industrialized countries' urban centers.[25]

Lifestyle, diet and genetic factors Obesity's multifactoral causes, as well as evidence in Cuba that obesogenic diet, the population's tastes and preferences,[24] and reduced physical activity[25] all contributed to excess body weight, led to additional studies to identify the role of each of these factors. To this end, 100 children (aged 6-12 years) and 100 adolescents (aged 13-15) from Havana, were included in case-control studies in 2012-2014.[20,21] All participants were apparently healthy, and had no history of infectious, inflammatory or chronic disease in the previous three months. High adiposity, measured by isotopic deuterium dilution, was strongly associated with chronic low-grade inflammation as measured by inflammatory cytokines, and also with hyperinsulinemia, high blood pressure and elevated cardiometabolic risk (indicated by levels of abdominal fat, blood pressure, HDL cholesterol, triglycerides, and serum glucose). A strong association was also found with substantial consumption of fast foods, sugary drinks, refined cereals, carbohydrates, sodium, and animal fat, as well as with total energy intake.[20,21]

Children and adolescents with excess body weight (defined as BMI $Z$ values $>2$, compared to the WHO's growth standards, 2007),[26] with $>30-40 \%$ body fat in some cases, had mean values of inflammatory indicators (such as C-reactive protein) seven times greater than those of normal-weight children. In this research, the increased adiposity was not associated with reduced physical activity, but rather with an obesogenic diet, the mother's excess body weight at conception, and both parents' excess weight.[20,21] Such findings corroborate that lifestyle changes affecting all children and adolescents, more markedly affect the most susceptible children, those with a family history of excess body weight.

\section{LOW BIRTH WEIGHT, POOR NUTRITIONAL MANAGEMENT OF LBW INFANTS, AND RISKS TO HEALTH}

WHO defines LBW as weight at birth of $<2500$ g.[27] Infants born with intrauterine growth retardation (IUGR) are those born weighing less than the 10th percentile of birth weight for gestational age, regardless of whether that weight is $<2500 \mathrm{~g}$. For purposes of this paper and Cuban studies cited, we refer only to full-term infants born between 37 and 42 weeks of gestation weighing $<2500 \mathrm{~g}$.

Children with LBW are more susceptible to glucose intolerance and excessive body fat accretion in later life. The well-recognized adaptive mechanism, described by David Barker in India and in European populations that suffered periods of famine during World War II, has been widely identified as contributing to the overweight and diabetes epidemic in developing countries, where children born with LBW live in societies replete with fast foods, sugary drinks and obesogenic diets.[28] Full-term LBW infants from undernourished mothers are epigenetically marked as "thrifty phenotypes" in that they maximize the use of nutrients to increase their chances of survival. This adaptation mechanism, essential for fetal survival, may be at work later in life, accounting for body fat accumulation, glucose intolerance and diabetes in poorly managed postnatal obesogenic settings aiming to gain in the first few years of life the weight these children failed to reach at birth.

Increased nutrient demand for the rapid growth of LBW infants should be met by frequent and exclusive breastfeeding because of their reduced gastric capacity and not yet fully developed gastrointestinal system. Unhealthy environments and bacterial or parasitic infections are additional conditioning factors that may have an adverse impact on their immune system, already compromised in utero and during the first few months of life.[28] 
Contrary to recommendations, full-term LBW infants in Cuba have accelerated growth[16-18] and consume excessive amounts of calories and sugar over the first months of life.[22] This fast growth is erroneously considered a success by doctors and families, although it puts the children on an excess weight-gain curve, in an attempt to counteract the intrauterine malnutrition that led to LBW.

Exclusive breastfeeding, healthy until six months of age, prevents malnutrition and buildup of excess body weight during childhood.[29] In 2000 and 2006, only $28.7 \%$ and $26.4 \%$ of Cuban newborns, respectively, were exclusively breastfed during the first 4 months of life; this rate increased to $49 \%$ in 2010-2011, which is to say that more than half the newborns did not benefit from exclusive breastfeeding.[30] Stopping exclusive breastfeeding before infants are six months old negatively impacts all of them, but particularly those with LBW, for whom breastfeeding is essential to ensure normal growth. Meeting these newborns' energy and nutrient requirements with low quality, high energy food and sugary drinks deficient in micronutrients, instead of exclusive breastfeeding followed by appropriate complementary feeding, contributes to adiposity, inflammation and glucose intolerance,[20,21] as well as anemia.[13]

\section{A COMPREHENSIVE APPROACH TO PREVENTING EXCESS WEIGHT GAIN IN CUBAN CHILDREN}

If factors contributing to the overweight and obesity epidemic in Cuban children are to be modified, we need a national program using a multisectoral approach that involves all government institutions with a role in controlling weight increases in children and adolescents.

The overall strategy should include concrete, systematic and nationwide actions to reinforce nutrition education and to improve food distribution and school nutrition; address the urgent need to ensure regular physical activity; and include additional training for health personnel. It should also concentrate on correcting nutritional management of full-term LBW infants, and pay greater attention to women's health in their reproductive years, even before pregnancy.

Media and school-based health promotion programs should place more emphasis on food and nutrition education, providing concrete guidance for preventing overweight and associated morbidities. Actions aimed at reducing sugar and salt content in food should be intensified, and the availability of sugary drinks and unhealthy fast foods in and around schools should be controlled. The National Plan for Urban and Suburban Agriculture's excellent results in boosting domestic production of fruits and vegetables[32,33] should be translated into increased consumption in child care centers and elementary schools. A joint 2014-2016 project led by INHA, in collaboration with the Ministry of Agriculture (Using nuclear techniques to assess the role of nutrition-sensitive agri-food systems in improving diet, health and nutritional status of vulnerable populations),[34] has been developed aimed at fulfilling this goal.

WHO recommends that children and adolescents have $60 \mathrm{~min}-$ utes of moderate or intense physical activity daily, equivalent to fast-paced walking or jogging. Physical exercises should be part of family life and health education. Urban design should meet the structural guidelines for facilitating regular physical activity in settings with a high population density.[34] Mandatory physical activity at least three times a week should be guaranteed and monitored in Cuban school curricula, reinforcing actions in urbanarea schools.

Targeted interventions for LBW infants $A$ comprehensive health policy initiative that provides the framework for ensuring healthy weight gain, and preventing glucose intolerance, diabetes and other NCDs, should include more concrete actions to avoid full-term LBW infants' rapid and excessive weight gain. Medical staff should be specifically trained to start interventions during women's reproductive years long before pregnancy, since low body weight and micronutrient deficiency in pregnant women affect intrauterine growth. Thus, the National Plan for Prevention of Anemia in Pregnancy should stress targeted actions for women of childbearing age, including the prevention of disease and of smoking during pregnancy.

Changes to current medical practices for care and monitoring of LBW infants should include such actions as renewed promotion of exclusive breastfeeding of infants until age six months, already in the 1989 National Maternal and Child Health Program. Also still relevant to the efforts to provide guidance on nutrition are the 1990s' Plan of Action for Implementing the World Declaration on the Survival, Protection and Development of Children and the Joint Program Support for the fight against anemia in vulnerable groups in Cuba, sponsored by the MDG Development Fund.

Diet and lifestyle of full-term LBW infants in their first years of life should ensure normal and not excessive growth in order to avoid body fat accumulation and glucose intolerance. Such a diet should include several appropriate-sized daily portions of food rich in micronutrients and low in sugar and salt, as well as strict limitation of fast foods. Parents or guardians and medical personnel should be well aware that increases in weight greater than those appropriate for age and sex do not represent a professional or family success, but rather jeopardize the future health of these children who are born with a higher predisposition to body fat storage.

\section{CONCLUSIONS}

The high prevalence of excess body weight in Cuba is undeniable. Associated NCDs are the first causes of death and the most frequent morbidities in the country, with diabetes mellitus, cancer and cardiovascular diseases on the rise. Health institutions invest time and resources to counteract this tendency, but the problem requires a comprehensive solution that the public health sector cannot achieve alone.

Well-structured, multisectoral preventive actions and policies will have a beneficial impact on reduction of overweight and NCDs, including programs addressing lifestyle and nutrition for families and their children. In this context, a comprehensive approach to prevent excess weight gain in childhood, with more precise guidance to mitigate risk factors, should be instituted. This should take particular aim at rectifying errors in nutritional management of full-term LBW infants, through concerted education of health professionals, parents and families. -1 - 


\section{REFERENCES}

1. WHO Multicentre Growth Reference Study. Assessment of differences in linear growth among populations. Acta Pædiatr. 2006;(Suppl 450):56-65

2. Yang Z, Huffman SL. Nutrition in pregnancy and early childhood and associations with obesity in developing countries. Matern Child Nutr. 2013 Jan;9 Suppl 1:105-19.

3. Jiménez S, Rodríguez A, Díaz-Sánchez ME. La obesidad en Cuba. Una mirada a su evolución en diferentes grupos poblacionales. Rev Cubana Alim Nutr. 2013;23(2):297-308. Spanish.

4. Franco M, Bilal U, Orduñez P, Benet M, Morejón A, Caballero B, et al. Population-wide weight loss and regain in relation to diabetes burden and cardiovascular mortality in Cuba 1980-2010: repeated cross sectional surveys and ecological comparison of secular trends. BMJ. 2013;346:1-9.

5. Barceló A, Díaz O, Norat T, Mateo de Acosta O. Diabetes mellitus en Cuba (1979-1989), I: variaciones relacionadas con edad y sexo. Rev Cub Endocrinol. 1993;4:59-66. Spanish.

6. Arnold Y, Castelo L, Licea M, Medina I. Comportamiento de indicadores epidemiológicos de morbilidad por diabetes mellitus en Cuba, 19982009. Rev Peruana Epidemiol [Internet]. 2012 [cited 2014 Apr 8];16(1). Available from: http:// rpe.epiredperu.net/rpe ediciones/2012 V16 N01/4AO Vol16 No1 2012 Comportamiento _indicadores_diabetes_mellitus.pdf. Spanish.

7. Fernández-Britto JE, Barriuso $A$, Chiang MT, Pereira A, Toros $\mathrm{H}$, Castillo JA, et al. La señal aterogénica temprana: estudio multinacional de 4934 niños y jóvenes y 1278 autopsias. Rev Cubana Invest Bioméd [Internet]. 2005 Sep [cited 2014 Jul 6];24(3). Available from: http://scielo .sld.cu/scielo.php?script=sci_arttext\&pid=S0864 $-03002005000300002 \&$ Ing=es. Spanish

8. Licea ME, Bustamante M, Lemane M. Diabetes tipo 2 en niños y adolescentes: aspectos clínicoepidemiológicos, patogénicos y terapéuticos. Rev Cubana Endocrinol [Internet]. 2008 Apr [cited 2014 Jul 6];19(1). Available from: http://scielo .sld.cu/scielo.php?script=sci_arttext\&pid=S1561 $-29532008000100007 \&$ Ing $=$ es. Spanish.

9. Pacheco Torres L, Piñeiro Lamas R, Fragoso Arbelo T, Valdés Alonso MC, Martínez R. Hígado graso no alcohólico en niños obesos. Rev Cubana Pediatr [Internet]. 2006 Mar [cited 2014 Jul 6];78(1). Available from: http://scielo .sld.cu/scielo.php?script=sci_arttext\&pid=S0034 $-75312006000100002 \&$ Ing=es. Spanish.

10. Barcelo A, Aedo C, Rajpathak S, Robles S. The cost of diabetes in Latin America and the Caribbean. WHO Bull. 2003;81:19-27.

11. Webber L, Kilpi F, Marsh T, Rtveladze K, Brown M, McPherson K. High rates of obesity and non-communicable diseases predicted across Latin America. PLoS One [Internet]. 2012 Aug [cited 2014 Apr 12];7(8). Available from: http://www.plosone .org/article/info\%3Adoi\%2F10.1371\%2Fjournal .pone0039589

12. The State of World Population 2011 - UNFPA [Internet]. New York: United Nations; 2011 [cited 2014 Apr 8]. Available from: http://foweb.unfpa .org/SWP2011/reports/EN-SWOP2011-FINAL .pdf

13. Pita-Rodríguez G, Jiménez-Acosta $S$, BasabeTuero B, Macías-Matos $\mathrm{C}$, Hernández M, CruzJorge $C$, et al. Moderate and mild anemia as public health problem in Cuban preschool children. Ann Nutr Metab. 2013;63(Suppl 1):319.

14. National Health Statistics and Medical Records Division (CU). Anuario Estadístico de Salud 2013 [Internet]. Havana: Ministry of Public Health (CU); 2014 Apr [cited 2014 May 26. Available from: http://files.sld.cu/dne/files/2013/04/anu ario_2013.pdf. Spanish.
15. Goldenberg RL, Culhane JF. Low birth weight in the United States. Am J Clin Nutr. 2007:85(Suppl):S584-90

16. Macías-Gelabert $A$, Hernández-Triana $M$, Ariosa-Abreu J, Alegret-Rodríguez M. Crecimiento prenatal y crecimiento posnatal asociados a obesidad en escolares. Rev Cubana Invest Bioméd [Internet]. 2007 Sep [cited 2014 Jul 6];26(3). Available from: http://scielo.sld .cu/scielo.php?script=sci_arttext\&pid=S0864 $-03002007000300002 \&$ Ing=es. Spanish.

17. Suárez-Rondón $M$, Ruiz-Álvarez V, AlegretRodríguez $M$, Hernández-Triana $M$, AriosaAbreu J. Crecimiento pre y postnatal asociado a obesidad en escolares de Bayamo, Cuba. Rev Cubana Invest Bioméd [Internet]. 2014 [cited 2014 Jul 6];33(2):104 -18. Available from: http:/ bvs.sld.cu/revistas/ibi/vol33_02_14/ibi11214 .htm. Spanish.

18. Galcerán-Chacón G. Crecimiento pre y postnatal asociado a sobrepeso corporal en escolares. Holguín 2007-2008 [thesis]. [Havana]: Nutrition and Food Hygiene Institute (CU); 2009. 98 p. Spanish

19. Puentes I, Cabrera A, Miranda-Díaz M, CaridadRomero M, Matos D, Hernández-Lozano M, et al Sugar intake in Cuban children and adolescents. Ann Nutr Metab. 2013;63(Suppl 1):1946

20. Hernández-Triana $M$, Ruiz-Álvarez $M$, DíazSánchez ME, Viera-Cosiñol C, Hernández Hernández $\mathrm{H}$, Pita-Rodríguez $\mathrm{G}$, et al. Body fat and inflammation in Cuban school children. Ann Nutr Metab. 2013;63(Suppl 1):1179.

21. Ruiz-Álvarez V, Díaz-Sánchez ME, RodríguezDomínguez L, Puig-Peña Y, Viera-Casiñol C Hernández-Hernández $\mathrm{H}$, et al. Body fat, inflammation and gut microbiota in Cuban adolescents. Ann Nutr Metab. 2013;63(Suppl 1):1195.

22. Fernández Díaz R, Ricardo Falcón T, Puente Perpiñán $M$, Alvear Coquet $N$. Factores de riesgo relacionados con la obesidad en niños menores de 5 años. Rev Cubana Aliment Nutr. 2011;21(1):101-9. Spanish.

23. Hernández-Triana $M$, Porrata $C$, Jiménez $S$, Rodríguez A, Carrillo O, García-Uriarte A, et al. Dietary reference intakes for the Cuban population, 2008. MEDICC Rev. 2009 Fall;11(4):9-16.

24. Porrata-Maury C. Cubans' deadly diet: a wakeup call. MEDICC Rev. 2008 Spring;10(2):52.

25. Hernández-Triana M. Fitness vs. obesity in Cuban children: battling the biases of gender and geography. MEDICC Rev. 2010 Spring;12(2):48.

26. de Onís M, Onyango AW, Borghi E, Siyam A, Nashidaa C, Siekmanna J. Development of a WHO growth reference for schoolaged children and adolescents. WHO Bull [Internet]. 2007 [cited 2014 Ju 6];85:660-7. Available from: http://www.who .int/growthref/en/

27. World Health Organization. International statistics classification of diseases and related health problems. 10th revision, Vol 2. Geneva: World Health Organization; 1993.

28. Vaag AA, Grunnet LG, Arora GP, Brøns C. The thrifty phenotype hypothesis revisited. Diabetologia. 2012;55:2085-8.

29. Moreno MA, Furtner F, Rivara FP. Breastfeeding as obesity prevention. Arch Pediatr Adolesc Med. 2011;165(8):772.

30. National Medical Records and Health Statistics Division (CU). Cuba. Encuesta de Indicadores Múltiples por Conglomerados 2010/11. Havana: Ministry of Public Health (CU); United Nations Children's Fund; c2007. Tabla NU.3; [cited 2014 Jul 6]; p. 44. Available from: http://www.child info.org/files/MICS3_Cuba_FinalReport_2006 Sp.pdf. Spanish

31. Companioni N. The Growth of Urban Agriculture. In: Funes F, García L, Bourque M, Pérez N, Ros- set $P$, editors. Sustainable Agriculture and Resistance. Oakland: Food First Books; 2002 Jan 15. p. 220-36

32. Koont S. The urban agriculture of Havana Monthly Rev. 2009;60(8):11-20.

33. Using nuclear techniques to assess the role of nutrition-sensitive agri-food systems in improving diet, health and nutritional status of vulnerable populations. IAEA.org [Internet]. Vienna: International Atomic Energy Agency; c2012; 2013 Aug [cited 2014 May 26]; [about 5 screens]. Available from: http://www-naweb.iaea.org/nahu/ NAHRES/crp/e43029.html

34. World Health Organization. Recomendaciones mundiales sobre actividad física para la salud [Internet]. Geneva: World Health Organization; 2010 [cited 2014 May 20]. 58 p. Available from: http://www.who.int/dietphysicalactivity/publica tions/9789241599979/es/. Spanish.

\section{THE AUTHOR}

Manuel Hernández-Triana (manumacondo@ hotmail.com; macondo@infomed.sld.cu),clinical biochemist. Full professor of clinical biochemistry, department of biochemistry and physiology, Nutrition and Food Hygiene Institute, Havana, Cuba.

Submitted: April 23, 2014

Approved for publication: April 26, 2015

Disclosures: None 